\title{
It's not only the economy, stupid! Good governance matters in elections
}

\author{
Diana Burlacu
}

\begin{abstract}
This paper examines the impact of good governance in elections compared to the role of the economy. The latter is considered the key factor in electoral survival, while governance issues are rarely included in politicians' discourse or campaigning strategies. Using the ParlGov data and the ICRG indicators for 160 elections, the analysis shows that good governance matters, but mainly for developing countries. Economic growth is an important electoral topic in most of the elections, but its effect varies systematically across contexts. The impact of each good governance and the economy gets weaker as the other worsens, and their conditional effects are moderated by the level of economic development.
\end{abstract}

Keywords: elections, economic voting, governance, corruption, three way interaction, simex 


\section{Introduction}

Elections are citizens' means to hold the government accountable for the economic, social, and institutional development of the country. A vast majority of electoral research focuses on the role of the economy and less on the importance of bad governance, with some exceptions in recent years. Regarding the impact of governance, researchers look at corruption as a proxy for good governance, and conclude that incumbents are punished for corruption only if they also underperform economically. This paper extends this research by considering the role of overall quality of governance in elections, and examines the conjuncted trade-off between good governance and the economy in countries with different levels of economic development. The results show that good governance and the economy moderate each others' effect, and contrary to the results in studies of corruption, incumbents are punished for bad governance even when there is economic growth. These findings are stronger in developed countries than in wealthy economies.

Previous studies of corruption (e.g. information about, allegations or individual evaluations of corruption) show that its effect on vote decision and electoral outcome is small (Fackler and Lin 1995; Hibbing and Welch 1997; Peters and Welch 1980) and that it is tolerated by voters as long as the economy is doing well (Zechmeister and Zizumbo-Colunga 2013; Klašnja and Tucker 2013; Choi and Woo 2010). It is however debatable whether voters close their eyes to bad governance in times of economic growth. Overall, governance affects a larger range of aspects of citizens' lives, voters having multiple sources of information regarding its performance. Dysfunctions in governance performance can be easily blamed on the government, while corruption "is not limited to the incumbent party, but [seen as] a problem of the overall political system or society in general" (Choi and Woo 2010: 259).

Good governance is expected to have a positive effect moderated by economic downturns, but a decline in the quality of governance can also reduce the impact of the economy on election results. Governance crises seem to make people less likely to base their voting decision on the state of the economy (Singer 2011b). Focusing only on the conditional role of economic growth on the effect of governance, one can dismiss an important aspect of the interdependence of good governance and the economy. Thus, this study examines both sides of this interaction, taking also into account that these relationships can vary across different levels of economic development. ${ }^{1}$

\footnotetext{
${ }^{1}$ Berry et al. (2012) show that researchers tend to focus only on one side of the interaction effects of two variables, and "[a]s a result, they either underestimate or, more worryingly, overestimate the support for their theories".
} 
Before examining the three-way interaction between economic growth, change in good governance, and economic development, in section 2 I consider shortly the previous literature on good governance and its consequences in electoral behavior, and discuss why governance is important in elections at the beginning of section 3. A theoretical model of the interdependent effects of good governance and economic conditions is proposed in subsection 3.1. The analysis in section 4 presents the aggregate level models of change in vote share, and the last section discusses its results and concludes.

\section{Good governance and accountability}

In the last two decades, the topic of well-performing institutions - good governance vs. malfunctioning governments - has increasingly attracted the attention of social scientists and international organizations. The discussion has moved from non-democratic vs. democratic regimes to well-functioning institutions vs. poor governance (Bok 2010; Helliwell 2006). In 1994, the United Nations Development Programme (UNPD) published a first document entitled Initiatives for Change stating the main goals of governance initiatives. Three years later, a first definition of governance was included in Governance for Sustainable Human Development: "the exercise of economic, political, and administrative authority to manage a country's affairs at all levels, comprising the mechanisms, processes, and institutions through which that authority is directed" (UNPD 1997). ${ }^{2}$

Good governance is not only a means to promote economic development in developing countries, but also a political norm in prosperous democracies. Well-performing institutions promote economic development (Rodrik et al. 2004), efficient public spending (Holmberg et al. 2009), political trust (Rothstein and Stolle 2008) and individual happiness (Bok 2010; Helliwell 2006). In electoral research, scholars demonstrate that evaluations of education or health care standards, or level of crime affect voters' support for the incumbent and/or its popularity (Bartle 2003; Clarke 2009; Erikson et al. 2002; Hobolt et al. 2012; Johnston and Pattie 2001). Other studies show that good governance aspects - ranging from crime rates and school performance league tables to measures of bureaucratic efficiency - matter in local elections (James and John 2007; Boyne et al. 2009; Oliver and Ha 2007). Among the good governance aspects, most of previous studies have focused on corruption. The ongoing debate is whether incumbents are punished for charges of corruption or not (Fackler and Lin 1995; Hibbing and Welch 1997; Peters and Welch

\footnotetext{
${ }^{2}$ Without a well-defined theory of governance, several definitions of governance and good governance have been used since good governance was first mentioned in an official document. See Grindle (2007) for a review.
} 
1980; Manzetti and Wilson 2007; Shabad and Slomczynski 2011). Recently, scholars have claimed that corruption is relevant in election only when economic performance is simultaneously under pressure (Zechmeister and Zizumbo-Colunga 2013; Klašnja and Tucker 2013). In the next section, I examine why incumbents are held accountable for changes in governance although they seem to escape punishment when there is high corruption. I also discuss how the effect of good governance is interdependent on the economy.

\section{Do voters react to the quality of governance?}

The "responsible party government model" states that voters control the incumbents based on their judgments of performance, and use their votes to punish or reward them (Jones and McDermott 2004; Ranney 1982). The literature on political accountability and performance-based voting is mostly about the role of the economy in elections, and shows that incumbents are rewarded for a well performing economy and punished for economic downturns, accordingly (Fiorina 1981; Hibbing and Alford 1981; Lewis-Beck and Stegmaier 2000). However, incumbents are also held accountable for fiscal policies, war casualties (De Mesquita and Siverson 1995) or natural disasters (Gasper and Reeves 2011; Healy and Malhotra 2009) . It is then expected that overall governance performance also affects incumbents' electoral support.

According to the scholarship on contextual effects, people are attentive to the environment surrounding them, and form opinions and evaluations based on personal observation, informal interaction, and mass media (Books and Prysby (1991), Cox (1969); see also Marsh (2002) for a critical review of contextual effects). Voters observe public officials and institutions, and evaluate their performance. In addition, they discuss about their experience with political actors, bureaucrats, and other public officials with other individuals, and adjust their perceptions accordingly. In countries with high levels of corruption, citizens expect the political institutions to control and punish corrupt politicians. In contexts with inefficient bureaucracies, individuals have to deal with red tape and incompetent public officials, and conclude that the bureaucratic system does not work. For those voters who try to build a business, governmental regulations and the ease of dealing with administrative issues give them cues to evaluate governance performance. Citizens also have perceptions on the level of crime, judicial efficiency, the performance of schools, hospitals, public transportation or communication systems in their community or other cities and weigh them in their assessments of government's effectiveness.

Incumbents are held accountable for the quality of governance in their mandate since 
the central government is the only actor involved in the governance process who is elected. In spite of the new processes of decentralizing the decision making power to non-governmental actors (private or public-private collaborations), the government still has the regulatory power over many social and economic issues, as well as the private or private-public contracts for service delivery and management. The incumbents at all levels have an important say in structuring the public sector or public-private collaborations. Voters can express their dissatisfaction with these services by sanctioning the government for the performance of the governance system.

Some may say that voters do not have the necessary information to assess the quality of governance and hold the incumbent accountable. Others argue that the paradox of ignorance (i.e. the claim that the rational voter is uninformed about economic and political issue) is exaggerated and, in fact, the degree of voter's lack of political knowledge is not that high (Aidt 2000). Citizens use cues efficiently to make reasonable decisions and evaluate officials' activity (Lupia 1998), and assess the economic conditions correctly and make accurate evaluations of governments performance (Kramer 1971; Lewis-Beck and Stegmaier 2000; Sanders and Gavin 2004). While some studies on governance show little correlation between the subjective and objective measures of government performance (Swindell and Kelly 2000; Van Ryzin 2008), others suggest that citizens are accurate in their predictions of the condition of public services in their community (Ostrom 1999), and similar subjective and objective indicators are statistically associated (Parks 1984). It is then plausible to assume that changes in the quality of governance are reflected in electoral support because voters can assess these changes and keep the incumbent accountable.

\subsection{The interdependent effects of good governance and economic conditions}

Recently, scholars have come up with the idea of a conditional corruption voting. ${ }^{3}$ Incumbents are punished for corruption or allegations of corruption only if they also underperform economically. Several theoretical arguments have been proposed to explain this conditionality: corruption is a second order concern behind the state of the economy (Klašnja and Tucker 2013: 537), voters trade off perceived political honesty for economic prosperity (Zechmeister and Zizumbo-Colunga 2013: 1195), or economic performance filters the information about corruption and voters do not assign the same weight to it

\footnotetext{
${ }^{3}$ See Klašnja and Tucker (2013) and Zechmeister and Zizumbo-Colunga (2013) for individual level, as well as Choi and Woo (2010) for aggregate level analysis.
} 
unless it is seen as the cause of economic decline, especially in developing countries (Choi and Woo 2010: 255).

Similar arguments from theories of issue salience (Krosnick 1990; Fournier et al. 2003), information-processing theory of attitude formation (Higgings and King 1981; Bizer and Krosnick 2001), or supply-side conditional economic voting hypotheses (Tucker 2006) can explain the interaction between the economy and good governance. Like corruption, the relevance of bad governance can be exacerbated by economic decline if voters see a link between good governance and economic growth, and consider the former a cause of the latter. However, it is debatable whether voters would close their eyes in front of bad governance if there is economic growth. Unlike corruption, overall bad governance affects a larger range of aspects of citizens' lives, thus economic growth should be less of a moderator of the government's overall performance. The economy may be the key to assure popular support, but voters are unlikely to enjoy it if the institutions and governance mechanisms are underperforming. Hence, incumbents receive voters' appreciation for economic performance, but they are punished for the difficulties and drawbacks that citizens encounter when interacting with political and public institutions.

Bad governance could also reduce the salience of economic performance by drawing people's attention away from the economy. As Singer argues, governance crises make people less likely to base their voting decision on the state of the economy (Singer 2011b) and even during a recession a significant part of the electorate base their vote on non-economic issues (Singer 2011a). The connection between good governance and the economy can be illustrated in four different scenarios: when both are in crisis, when either one or the other is badly affected, and when both are in good shape. Given that previous studies assume a stronger punishment for both bad governance and economic recession, I define $\alpha$ as the threshold for an economic crisis and $\beta$ for the threshold for a governance crisis:

1. economic growth $<\alpha$ and change in good governance $<\beta$ : both variables are expected to have a strong role in elections.

2. economic growth $>\alpha$ and change in good governance $<\beta$ : good governance is the salient issue in elections and the economy matters less than in (1).

3. economic growth $<\alpha$ and change in good governance $>\beta$ : the economy is the salient issue in elections and good governance matters less than in (1) or (2).

4. economic growth $>\alpha$ and change in good governance $>\beta$ : considering that "the economy is always an important issue to voters" (Wlezien 2005: 556), I expect economic growth to have the main role in election outcomes. 
In a nutshell, the effect of good governance or the economy gets weaker as the other worsens. When both decline the incumbent loses the most. Overall, the effect of the economy is expected to be stronger than the one of the quality of governance. This expectations are partially grounded on the valence politics theory. Both good governance and economic growth are valence issues (Stokes 1963, 1992): everyone supports less corruption, better governance and economic growth. According to the scholarship on valence politics, incumbents are replaced based on their competence and performance on these issues only if the rival is better equipped to govern (Ho et al. 2013; Clarke and Whitten 2013). Poor improvements in corruption and good governance can then remain unpunished if voters do not have better options to choose from, or if incumbents show competence in other sectors. In scenarios 2, 3 and 4, incumbents may still seem a better alternative given their performance on the other issue, while in case 1 their failure on both economic growth and institutional performance can make the opposition seem like the lesser of two evils.

The $\alpha$ and $\beta$ thresholds may however differ across countries. In some socio-economic contexts people are more resilient or permissive than in others and the magnitude of economic (and here good governance) voting depends then on the social settings and the historical context Lin (1999). In this case, it is the level of economic and institutional development that is expected to condition individuals' perceptions of governance or economic crises and their effects on election results.

Choi and Woo (2010), and Zechmeister and Zizumbo-Colunga (2013) show that in developing countries incumbents are punished for corruption only when the economy worsens too. The experiments done by Klašnja and Tucker (2013) have similar results in a high corruption country (Moldova), which also has a low level of economic development, but not in a low corruption country (Sweden), which is also a highly developed economy. In the latter, voters react negatively to corruption regardless of the state of the economy. I expect that the four scenarios above are present in developing countries and/or those with poor governance because voters are willing to overlook underperformance in one area when the goal in the other sector is met. As countries develop economically and institutionally, voters are expected to become less permissive and thus the conditional relation between economic growth and change in good governance should is eroded. 


\section{Research design}

In this section, I test empirically the above relationships. Previous studies focused mostly on the role of corruption, measured in absolute terms rather than the change in performance. I extend the analysis to the overall quality of governance and test the effect of both change and absolute level. In this way, the results are not driven by the fact that voters in countries with a persistent level of corruption/bad governance may not punish the incumbent because no changes have occurred during the term. Because of the low level of change in the corruption control indicator (in less than $25 \%$ of cases in the sample), this section presents only the results from models with good governance. ${ }^{4}$

For models of incumbent support explained by changes in the quality of governance, data for the vote share of the incumbent and corresponding indicators of the quality of governance for two consecutive elections are necessary. The ParlGov database (Döring and Manow 2010) provides the election results for 38 European and OECD countries between 1900 and 2012. The International Country Risk Guide (ICRG 2012) has indicators of good governance available for all elections between 1984 and 2011 (which includes more cases than other datasets, e.g. the World Bank indicators of good governance which are available only from 1996). The analysis focuses thus on 160 parliamentary elections between 1984 and 2011 in 31 countries. ${ }^{5}$ I had to exclude the elections when the prime minister's party was in a pre-electoral alliance or the party split during the electoral cycle, because of the level of error involved in disentangling its vote share from the vote share of the alliance.

Each case is an election in country $c$ at time $t$. Because the elections when the primeminister's party was in a pre-electoral alliance or the party split during the electoral term disrupt the country time series, I cannot use panel data analysis, but still have to control for the dependence between multiple elections in the same country. To do that, I use the Huber-White standard error clustered according to country. ${ }^{6}$ The dependent variable is change in vote share of the prime minister's party since the last elections. Thus, I run OLS regressions with clustered standard error. Similar results are obtained when support for the incumbent is estimated as the change in overall vote share for the coalition parties

\footnotetext{
${ }^{4}$ The ones with corruption are available in the online Appendix, but should be interpreted with precaution.

${ }^{5}$ Countries included in the analysis: Australia, Austria, Belgium, Bulgaria, Canada, Cyprus, Czech Republic, Denmark, Spain, Estonia, Finland, France, Germany, Great Britain, Greece, Hungary, Iceland, Ireland, Italy, Japan, Lithuania, Luxembourg, Latvia, Malta, Netherlands, Norway, New Zealand, Poland, Portugal, Slovakia, Slovenia, Sweden

${ }^{6}$ See Moulton (1986) and Wooldridge (2003) for several applications of cluster-sample methods and Hellwig and Samuels (2008) for an example of using cluster standard error in economic voting models.
} 
in the cabinet. For elections when several cabinet changes took place during the electoral term, I considered the change in vote share for the prime minister of the last cabinet formed before the elections.

The key independent variable is point change in good governance in the election year, with high values indicating an improvement in the quality of governance. It is measured using the International Country Risk Guide (ICRG 2012) indicators of political risks in a country.Good governance is calculated as the average of corruption (i.e. excessive patronage, nepotism, job reservations, favor-for-favors, secret party funding, and suspiciously close ties between politics and business), bureaucratic efficiency (i.e. whether the bureaucracy is autonomous from political pressure, has an established mechanism for recruitment and training, and can govern without drastic changes in policy and interruption in government services), business regulation (i.e. an assessment of factors affecting the risk to investment: contract viability/expropriation, profits repatriation and payment delays), and judicial effectiveness (an assessment of the strength and impartiality of the legal system and of popular observance of the law). ${ }^{7}$ The ICRG indicators are based on the evaluations of the Political Risk Group (PRG) editors using pre-set questions about the political risk in each country. These are calculated using identical rules for all countries, which makes the cross-national and cross-time comparison possible, as opposed to other indicators of governance based on public opinion or expert surveys (e.g. World Bank Worldwide Governance Indicators or Transparency International indicator of Control of Corruption).

Compared to the volatile leading indicators of economic conditions (e.g. unemployment, inflation), quality of governance is a slowly changing dimension of government performance. In the sample, the level of corruption remained constant in over $76 \%$ of elections, the overall governance in $32 \%$ of cases. The biggest drop in overall governance was -0.28 in Austria in 1994, while the biggest improvement was 0.58 in Malta in 1992. One could then argue that voters have a hard time observing any changes in the quality of governance in the year prior to elections, but they could react to cumulative performance throughout the term. Models including these measures of change have similar results, which indicates that for the quality of governance as for economic growth, voters substitute election-year performance for the entire term (Healy and Lenz 2014), though a positive change in governance in the election year is not always associated with an overall improvement throughout the term $(\mathrm{r}=.52)$.

\footnotetext{
${ }^{7}$ Some of the indicators were initially measured on a 0 to 4,6 or 12 point scale. They were all recoded into a $0-6$ scale
} 
Given that the main focus of the paper is on the conjuncted trade-off between good governance and the economy, the other two important independent variables are economic growth, measured as the year percent change in real GDP in the election year (from International Monetary Fund (2013)), and the economic development level, calculated as the logarithm of GDP per capita (from International Monetary Fund (2013)). As expected, overall governance and economic development level are highly correlated (Kaufmann et al. 2007b, a; Kurtz and Schrank 2007), but the correlation between economic growth and change in good governance is weak. The absolute level of governance and corruption control appears to be associated with changes in the economy or governance only in developing countries. While economic growth is positively correlated with governance performance $(\mathrm{r}=.26)$, its correlation with corruption control is negative $(\mathrm{r}=-.13)$. Higher levels of corruption do bring faster economic growth in developing countries (Choi and Woo 2010), but bad governance seems to hinder it.

To address potential differences in government support due to the democratic quality, I control for democratic experience (measured in years since the country had the first democratic election, from the Polity database (Marshall and Jaggers 2012). The number of years of democracy is preferred to the polity rating measure, since the latter includes other aspects of institutional quality that could be directly linked to governance indicators. I also control for whether the incumbent is a coalition, and if the election took place after the economic recession in 2008. To take into account the stable base of political parties given the partisanship and social cleavages in the country, I include previous vote share for the incumbent in the previous elections from the same ParlGov database (Döring and Manow 2010). Powell Jr and Whitten (1993) argued that using the results from previous elections gives identical coefficients in models with incumbent vote share or change in incumbency's vote share as dependent variable. These models measure then how change in governance and the economy alters the base of support of the incumbent.

The next section presents different models of electoral support for the prime minister's party explained by change in good governance (Models 1-5 in Table 1). To examine the conditional relationship between the impact of economic growth and change in the quality of governance, I include an interaction term between them. Also, to account for the differences in this conjuncted trade-off in countries with different levels of economic development, a three-way interaction term with change in good governance, economic growth and the level of wealth is considered. ${ }^{8}$.

\footnotetext{
${ }^{8}$ Models with the three-way interaction between level of good governance, economic growth and change in good governance are only presented in the online Appendix since all the interactions with the current level of the quality of governance are not statistically significant and do not improve the goodness of fit
} 


\subsection{Results}

The models in Table 1 test the magnitude and significance of different interactions between economic development, change in the quality of governance, and economic growth that are part of the three-way interaction in model 5. The results in model 1 - with no interaction terms - indicate that incumbents benefit out of improvements in good governance and the economy. Both indicators are positively associated with vote share, and their coefficients are statistically significant. ${ }^{9}$ Thus, prime minister's party receives on average $1.13 \%$ extra votes for a 0.1 point increase in governance effectiveness and $0.6 \%$ votes for $1 \%$ economic growth. ${ }^{10}$ The impact of the quality of governance in elections is comparable to the role of the economy (i.e. one standard deviation increase in economic growth or the quality of governance is associated with $1.5 \%$ or $1.8 \%$ increase in the vote share, with their $95 \%$ confidence intervals overlapping). These results reflect the averaged effects of these two independent variables across the observed range of economic wealth level, economic growth, or change in good governance. Models 2-5 show that these effects are, in fact, moderated by the other two predictors. Before discussing these models, a brief presentation of the control variables is necessary.

[Table 1 - about here]

Incumbents with a large base - a high absolute vote in the previous elections - lose electoral support easier in the next elections. The positive statistically significant coefficient of economic wealth shows that, all else being equal, incumbents have an advantage in prosperous democracies. The other control variables do not have statistically significant coefficients, but if they had, their effect would have been as expected. In a coalition, the prime minister's party is more vulnerable and loses more of its previous support than if it was a single-party cabinet. As countries get more democratic, the electorate is less supportive towards the chief executive, and after 2008, the incumbents have lost more votes than before the financial crisis.

The conjuncted trade-off between change in good governance and economic growth in models of electoral support for the incumbent is tested empirically using Interaction 1 in Model 2. The increase in the R-squared ${ }^{11}$ is very small, thus a conservative scholar would consider this interaction substantially insignificant. Before testing the strength of

\footnotetext{
${ }^{9} \mathrm{~A}$ coefficient is considered statistically significant at $5 \%$ significance level.

${ }^{10}$ Given that the observed range of economic growth (-7 to $\left.12 \%\right)$ and change in good governance (-0.3 and 0.6$)$, the discussion of the coefficients is done for a 0.1 increase in good governance and $1 \%$ economic growth.

${ }^{11}$ Because the standard errors are based on the robust variance estimator, the likelihood-ratio tests are not appropriate, thus I do not report this criterion of goodness of fit.
} 
this trade-off for different levels of economic wealth in Model 5, the interaction between change in good governance and economic development (Interaction 2) was included in Model 3, and the one between economic growth and development (Interaction 3) in Model 4. While, the latter improves only slightly the goodness of fit in model 4 , the interaction of economic wealth with change in good governance has all three constituent coefficients statistically significant and the best model fit in Table 1 . Only model 5, with all four components of the three-way interaction, has a slightly higher R-squared, but with three extra predictors. The results of a Wald test, hypothesizing that the coefficients of these three variables are simultaneously equal to zero, does not reject the null hypothesis, thus model 5 is not a better model than model 3. However, we cannot know whether the effect of change in good governance or/and economic growth is conditional on the level of economic wealth only by looking at the coefficients (Berry et al. 2012). Figures 1 to 3 present thus the marginal effects of the interaction components in Models 2 to 5. Conservative readers may disregard the results in Model 2, 4 and 5 because of the insignificant change in the R-squared, others will be interested in the magnitude of the conditional effects despite the small change in goodness of fit.

[Figure 1 - about here]

Figure 1 presents the marginal effect of change in good governance across the observed range of the economic growth (the left-hand-side graph). Contrary to previous research, this figure shows that the effect of change in good governance increases with more economic growth and becomes insignificant in times of economic crisis or stagnation. Governance improvement brings more votes to the incumbent if there is an economic growth of at least $2 \%$. It seems that changes in the quality of governance do not matter in elections when there is high economic growth (higher than $8.7 \%$ ), but this insignificant result can be an artefact of the isolated extreme values of the variable on the $\mathrm{x}$-axis in Figure 1 (Berry et al. 2012).

Figure 1 also presents the other side of the interaction between economic growth and change in good governance: the marginal effect of economic growth across the observed range of change in good governance (the right-hand-side graph). As predicted, the economy matters less in elections in times of governance crises. Economic effects appear insignificant for changes in good governance smaller than -0.14 or higher than 0.24 . Given that these represent only $11 \%$ of cases in the dataset, which includes several postcommunist countries in transition, the results should be interpreted with precaution and not generalized for older democracies without additional research. When statistically sig- 
nificant, the impact of change in good governance and economic growth is comparable. ${ }^{12}$

[Figure 2 - about here]

The results in Figure 2 complement the findings from Figure 1 by showing the marginal effect of change in good governance and economic growth across the observed range of economic development. The exponential decline in the marginal effect of change in the quality of governance on vote share is explained by the logarithmic transformation of economic development, measured as GDP per capita. ${ }^{13}$

Incumbents can significantly improve their electoral outcome with an increase in overall governance or positive economic growth in countries with a poor economy. When the level of development is higher than $\$ 18,000$ or $\$ 35,000$, the marginal effects of change in the quality of governance or economic growth respectively, are statistically insignificant (i.e. the $95 \%$ confidence interval includes 0 ). In models with cumulative change in good governance, its effect is statistically insignificant only in countries with a GDP per cap higher than $\$ 40,000$, which can be explained by the relatively small annual changes in good governance in OECD countries compared to economies in transition. When GDP is low and the institutional system is not well developed, any change is perceptible during the course of a year, compared to changes in well grounded systems where people may notice them only throughout the electoral cycle.

Improvements in the quality of governance or the economy bring twice as many votes in developing economies compared to countries with an average level of wealth. For the former, one standard deviation increase in good governance or economic growth leads to an increase of up to $5 \%$ votes in the vote share, while for the latter, the same change is associated with only $2 \%$ extra votes. These findings confirm partially the results from previous studies: in bad economic conditions, seen as low level of economic development, corruption and other institutional malfunctions weigh more in elections. The same seems to apply to the economy: in wealthy countries, other factors than the economic growth get on the public agenda during the elections. If we consider that good governance is highly correlated with economic wealth, the insignificant marginal effect of economic growth for low values of economic development in Figure 2 may confirm Singer's (2011) expectation

\footnotetext{
${ }^{12}$ The marginal effects were calculated for 1 standard deviation increase in both graphs for this kind of comparison.

${ }^{13}$ Using the logarithmic indicator improves the goodness of fit in models 1-5 and makes the interaction statistically relevant in model 2 in Table 1 . As the histogram of economic wealth shows in Figure 2, the economy reached a level higher than $\$ 50.000$ per capita in only few election years . Using its logarithmic transformation in the interaction with change in the quality of governance, the results in this figure are not driven by the extreme values Berry et al. (2012). Then, excluding these elections from the analysis does not change the results significantly.
} 
that in times of governance crises, the economy is less relevant in elections.

[Figure 3 - about here]

In Figure 1, we saw that below a $2 \%$ increase in the economy and a 0.14 decline in the quality of governance the effect of change in good governance and economic growth, respectively, are insignificant. Thus, these levels can be the $\alpha$ and $\beta$ thresholds proposed in the theoretical section 3.1, and the relationships presented in Figure 1 describe partially the scenarios 2 to 4 . As hypothesized in the same section, these thresholds may differ in countries with different levels of economic wealth. Figure 2 shows that the level of development constrains the effects of economic growth and change in good governance, and Figure 3 indicates that the absolute level of GDP affects also their contingent tradeoff.

The strongest effect of change in good governance is found in poor democracies when economic growth is high. A more moderate effect, which increases only slightly with the economic growth, is in countries with an average level of wealth, and almost no effect in developed economies. However, the only statistically significant impact appears to be in countries with a low level of wealth when the economic growth is higher than $2 \%$ but lower than $9 \%$ (similar to the results in Figure 1).

Economic growth has also the strongest effect in poor economies and the weakest in wealthy countries. In the former, the impact of the economy on incumbent's support increases with improvements in good governance, while in the latter the poor governance makes it stronger. The marginal effect appears to be statistically significant only for moderate changes in governance (similar to the results in Figure 1) when the development level is higher than its mean.

An easier to grasp illustration of the interdependent effects of economic growth, change in good governance, and economic development in Figures 1 to 3 is presented in Table 2 which includes the expected change in vote share for different values of these three predictors. These are estimated based on the results from model 5 in Table 1 for single party cabinets, with $34 \%$ vote share in previous elections, in countries with 46 years of democracy, and a four point overall governance, before the economic crisis in $2008 .^{14}$

[Table 2 - about here]

All four scenarios proposed in the theoretical section can be identified among the 27 combinations in Table 2. In the first scenario, where both economic growth and change

\footnotetext{
${ }^{14}$ The continuous independent variables are held at their mean, except for overall governance, which is set at a value of 4 (its mean is 5).
} 
in good governance are below a threshold (here one standard deviation below the mean), incumbents lose almost $10 \%$ votes in emerging economies, but no more than $2 \%$ in well developed countries. These are, however, the worst outcome in Table 2. In scenarios 2 and 3 , when only one of the predictors is below the threshold (Low), incumbents experience the same negative result in poor countries, losing almost $8 \%$ if one of these is at an average level, and around $6 \%$ if the other increases to a high level (here, mean plus one standard deviation). Prime ministers in countries with average or high economic wealth prefer the second scenario, where the quality of governance declines below the threshold but the economy is not affected. In these cases, in highly developed countries, they lose less than $1 \%$ of votes for an average economic growth, but can also win a bit more than that in the case of a $5 \%$ rise in the economy. The expectations from the fourth scenario, that the economy matters more than good governance when both exceed the threshold, are validated in countries with an average or high economic development. In emerging economies, the electoral benefits are the same if the economy or the governance improves.

\subsection{Error in change in censored governance indicators}

The ICRG indicators are scales from 0 to 6 , so for values higher than 4 , change in governance cannot exceed 2. Therefore positive changes are not reported, which could lead to measurement error and thus, biased and inconsistent coefficients. To see how the impact of governance and the economy would differ if the indicators of change in governance would not be measured with error, I use the method of simulation extrapolation for fitting models with additive measurement error (SIMEX) (Hardin et al. 2003). Because replicate measurements of governance were not available, I approximated the error variance of the indicators of good governance and its change for a $80 \%$ or $90 \%$ reliability level (i.e. $100 \%$ minus the reliability levels).

[Figure 4 - about here]

Figure 4 shows the coefficient estimates for change in quality of governance and economic growth in Model 1 (Table 1) when quality of governance in the last elections and the change of governance is measured with error. I calculate the coefficients of change in governance and economic growth for two situations: when the reliability of governance and change in governance is $80 \%$ (upper graphs) or $90 \%$ (lower graphs). I assume the covariance between the errors of both indicators to be 0 . The estimated coefficients are calculated as a quadratic extrapolant of the scale factor $\lambda \mathrm{j}$ (lambda), for how much extra measurement error is added to the error-prone variable. The dots represent the average of the estimated coefficients from 50 runs (simulations) for each scale factor $\lambda \mathrm{j}$ (lambda). 
When $\lambda=0$, the estimate is the coefficient from a naive regression, where we assume that our indicator was measured without error. When $\lambda=-1$, the estimate is the simex estimate accounting for the measurement error for $90 \%$ or $80 \%$ reliability. Higher values of lambda represent extra measurement error in variable change in good governance. The differences between the simex and naive estimate are significantly smaller when one excludes the level of good governance from the model.

The estimated coefficients and effects of change in good governance are higher when one controls for the measurement error, and the coefficients of economic growth are biased towards higher positive values when there is measurement error in the change in governance. Using the simex method, however, does not solve the recent issues in methodological debates concerning the uncertainty in the estimation and nature of the governance indicators (Bovaird and Löffler 2003; Devarajan 2008).

One of these concerns refers to the validity of the ICRG indicators. Its concepts are based on expert evaluations, which can be considered approximations of the objective measures of the quality of governance. In the analysis, I assume that the link between objective good governance and the ICRG indicators is accurate. However, two important nonrandom errors can erode this link. First, experts' subjective opinions on good governance can affect their evaluations. Thus, the actual level of good governance in the country is compared to an ideal type as perceived by the ICRG editors. One can assume that this ideal type is based on internationally-recognized principles and standards and this makes the indicators adequate for comparative studies, but voters in each country might have their own ideal type that they keep the government accountable for. Secondly, some scholars criticized the ICRG indicators for being driven to an important extent by large scandals in the country considered. This means that the ICRG editors are more likely to update the political risks measures when corruption control, regulatory quality, judicial effectiveness or bureaucratic efficiency are on the public agenda. If this is true, then the results in this paper should be read as showing that incumbents lose votes when governance issues attract public attention.

\section{Discussion and conclusions}

The aim of this paper was to estimate the impact of good governance in elections compared to the role of the economy. Previous research has focused on economic growth as one of the key elements for incumbents' survival. Several other scholars look at corruption and argue that it matters only when there is economic decline. The analysis in this paper 
confirms and, at the same time, contradicts these results: good governance matters more in poor economic contexts, but this contingent effect depends on the level of economic wealth and not on the economic growth in the election year. There is, in fact, a positive interdependent relationship between the effects of economic growth and change in good governance: each has a stronger effect when the other increases, but almost no effect for the other's extreme negative values. In addition, the level of economic development moderates not only the effect of the quality of governance, but also the role of the economic growth in election results. Both weigh more in incumbents' survival in developing countries than in well established economies.

For economic voting scholars, the contingency of economic growth on the level of wealth may come as a surprise. The results illustrate that the salience and the role of the economy vary systematically across countries with different levels of economic development (Singer 2011b; Lin 1999). Its insignificant effect in highly developed countries may indicate that voters in these countries weigh other factors more in their decisions, but conservative researchers may question this effect given the poor goodness of fit in model 3 (Table 1).

There also seems to be little empirical evidence that the quality of governance matters in developed economies. This may not be a salient issue in voters' minds because it had already achieved a high level of performance and, apart from temporary political scandals on corruption and bureaucratic inefficiency, public agenda is not about governance. Or, given that highly developed countries also have good governance performance, any change in this direction is too small to be quantified by the ICRS editors in their evaluations or by voters in their decisions.

When it comes to the conjuncted trade-off between good governance and the economy, the analysis shows that, contrary to the already established belief that the economy is always important and bad governance matters only when the economy also worsens, when there is bad governance, the economy matters less than under good governance; and in times of economic decline the quality of governance becomes less important. When both worsen, their cumulative effect makes it more likely for the incumbents to be thrown out. These findings support my theoretical assumption that incumbents' failure in both areas makes the opposition seem like a better option. These results hold mostly for developing countries, where governance and the economy have the same effect in elections. In countries with a level of economic development above the average, the role of the economy outplays the impact of governance in elections.

The discrepancy between the established view in the literature and the above results can be explained by the fact that I examine the overall good governance and test the effect 
of change, while the other scholars consider only one of its components, corruption, and look at its absolute level. The effect of cumulative change in corruption on election results is three times smaller than the effect of change in overall governance. ${ }^{15}$ If we focus only on corruption we disregard other aspects of good governance that are relevant for the development of a country and, apparently, for incumbents' electoral survival.

It is also interesting that elections in developing countries are characterized by a high electoral volatility that makes incumbents lose parts of their previous support even when there is economic growth or positive change in the quality of governance. They can only reduce the strong negative effects of volatility with high improvements in governance and economic performance. This may explain why in some countries, voters seem to forgive and forget incumbents' misperformance, while in others, the rascals are thrown out for small economic or institutional drawbacks.

If we assume that a low economic development level is highly associated with weak inefficient institutions, the results in this paper seem to contradict Manzetti and Wilson's(2007) findings that people do not throw out the corrupt rascals in countries with weak government institutions. However, Manzetti and Wilson (2007) look at individual perceptions, while the analysis in this paper considers the impact of aggregate governance. Perceptions of corruption/bad governance can weigh less in voters decisions if corruption is a persistent condition, but any drop can still be associated with fewer votes to the incumbent. Nevertheless, this analysis does not make inferences about voters' perceptions of governance performance and how much these matter in vote decisions. I only examine the link between change in good governance and election outcomes at the aggregate level. Future research will show whether individual assessments of the quality of governance correlate with changes in the ICRG or World Bank indicators and whether this judgment is considered in the final vote decision. Governance evaluations can be a key independent factor explaining voting behavior or they can be only one of the many issues voters weigh in their evaluations of government performance.

Overall, this paper shows that, as economic voting models predicted, economic growth is an important electoral topic in most of the elections. Quality of governance, interestingly matters the most in developing economies. Thus, incumbents in these countries should aim to achieve higher levels of good governance not only because of aid conditionality or international pressure, but also because of electoral pressure. Governance and the economy are interconnected systems and a chief executive cannot focus the resources either on promoting economic growth or good governance. Development is contingent

\footnotetext{
${ }^{15}$ Models not included in the paper but available in the online Appendix.
} 
on good political institutions and, at the same time, fosters good governance. Thus, neglecting governance to the detriment of the economy, or the other way, is not sound and governments need to find a balance between the two if they want to stay in power, especially in developing economies. The results of this paper have important implications for the general debate on electoral democracy. The aim is to have not only a democratic system focused on economic development, but also a well-performing governance that assures transparency, accountability, efficient business regulations, a low level of crime and corruption. 


\section{References}

Aidt, T. S. (2000). Economic voting and information. Electoral Studies 19(2), 349-362.

Bartle, J. (2003). Partisanship, performance and personality competing and complementary characterizations of the 2001 british general election. Party Politics 9(3), $317-345$.

Berry, W. D., M. Golder, and D. Milton (2012). Improving tests of theories positing interaction. Journal of Politics $74(3), 653-671$.

Bizer, G. Y. and J. A. Krosnick (2001). Exploring the structure of strength-related attitude features: the relation between attitude importance and attitude accessibility. Journal of Personality and Social Psychology 81(4), 566.

Bok, D. (2010). The politics of happiness: What government can learn from the new research on well-being. Princeton University Press.

Books, J. W. and C. L. Prysby (1991). Political behavior and the local context. Praeger Publishers.

Bovaird, T. and E. Löffler (2003). Evaluating the quality of public governance: indicators, models and methodologies. International Review of Administrative Sciences 69(3), $313-328$.

Boyne, G. A., O. James, P. John, and N. Petrovsky (2009). Democracy and government performance: Holding incumbents accountable in english local governments. The Journal of Politics 71 (4), 1273-1284.

Choi, E. and J. Woo (2010). Political corruption, economic performance, and electoral outcomes: A cross-national analysis. Contemporary Politics 16(3), 249-262.

Clarke, H. D. (2009). Performance politics and the British voter. Cambridge University Press.

Clarke, H. D. and G. D. Whitten (2013). Hard choices in hard times: Valence voting in germany 2009. Electoral Studies 32(3), 445-451.

Cox, K. R. (1969). The voting decision in a spatial context. Progress in Geography 1(1), 81-117.

De Mesquita, B. B. and R. M. Siverson (1995). War and the survival of political leaders: A comparative study of regime types and political accountability. American Political Science Review 89(4), 841-855.

Devarajan, S. (2008). Two comments on "governance indicators: where are we, where should we be going?" by daniel kaufmann and aart kraay. The World Bank Research Observer 23(1), 31-36. 
Döring, H. and P. Manow (2010). Parliament and government composition database (parlgov). An infrastructure for empirical information on parties, elections and governments in modern democracies. Version 10(11), 6.

Erikson, R. S., M. B. MacKuen, and J. A. Stimson (2002). The macro polity. Cambridge University Press.

Fackler, T. and T.-m. Lin (1995). Political corruption and presidential elections, 19291992. Journal of Politics 57, 971-993.

Fiorina, M. P. (1981). Retrospective voting in American national elections. Yale University Press.

Fournier, P., A. Blais, R. Nadeau, E. Gidengil, and N. Nevitte (2003). Issue importance and performance voting. Political Behavior 25(1), 51-67.

Gasper, J. T. and A. Reeves (2011). Make it rain? retrospection and the attentive electorate in the context of natural disasters. American Journal of Political Science 55(2), $340-355$.

Grindle, M. S. (2007). Good enough governance revisited. Development policy review 25(5), 533-574.

Hardin, J. W., H. Schmiediche, and R. J. Carroll (2003). The simulation extrapolation method for fitting generalized linear models with additive measurement error. Stata Journal 3(4), 373-385.

Healy, A. and G. S. Lenz (2014). Substituting the end for the whole: Why voters respond primarily to the election-year economy. American Journal of Political Science 58(1), $31-47$.

Healy, A. and N. Malhotra (2009). Myopic voters and natural disaster policy. American Political Science Review 103(3), 387-406.

Helliwell, J. F. (2006). Well-being, social capital and public policy: What's new?*. The Economic Journal 116(510), C34-C45.

Hellwig, T. and D. Samuels (2008). Electoral accountability and the variety of democratic regimes. British Journal of Political Science 38(01), 65-90.

Hibbing, J. R. and J. R. Alford (1981). The electoral impact of economic conditions: who is held responsible? American Journal of Political Science 25 (3), 423-439.

Hibbing, J. R. and S. Welch (1997). The effects of charges of corruption on voting behavior in congressional elections, 1982-1990. The Journal of Politics 59(1), 226-239.

Higgings, E. and G. King (1981). Accessibility of social constructs: information processing consequences of individual and contextual variability. In G. Cantor and J. Kihlstrom (Eds.), Personality, cognition and social interaction, pp. 69-121. Erlbaum. 
Ho, K., H. D. Clarke, L.-K. Chen, and D. Lu-Chung Weng (2013). Valence politics and electoral choice in a new democracy: The case of taiwan. Electoral Studies 32(3), 476-481.

Hobolt, S., J. Tilley, and S. Banducci (2012). Clarity of responsibility: How government cohesion conditions performance voting. European journal of political research 52(2), $164-187$.

Holmberg, S., B. Rothstein, and N. Nasiritousi (2009). Quality of government: what you get. Annual Review of Political Science 12, 135-161.

ICRG (2012). International country risk guide (icrg) researchers' dataset (academic): International country risk guide (icrg) researchers' dataset (academic): International country risk guide (icrg) researchers' dataset. http://www.prsgroup.com/ICRG.aspx.

International Monetary Fund (2013). World Economic Outlook (WEO). International Monetary Fund: International Monetary Fund.

James, O. and P. John (2007). Public management at the ballot box: Performance information and electoral support for incumbent english local governments. Journal of Public Administration Research and Theory 17(4), 567-580.

Johnston, R. and C. Pattie (2001). Dimensions of retrospective voting economic performance, public service standards and conservative party support at the 1997 british general election. Party Politics 7(4), 469-490.

Jones, D. R. and M. L. McDermott (2004). The responsible party government model in house and senate elections. American Journal of Political Science 48(1), 1-12.

Kaufmann, D., A. Kraay, and M. Mastruzzi (2007a). Growth and governance: A rejoinder. The Journal of Politics 69(02), 570-572.

Kaufmann, D., A. Kraay, and M. Mastruzzi (2007b). Growth and governance: A reply. Journal of politics 69(2), 555-562.

King, G., M. Tomz, and J. Wittenberg (2000). Making the most of statistical analyses: Improving interpretation and presentation. American Journal of Political Science $44(2), 347-361$.

Klašnja, M. and J. Tucker (2013). The economy, corruption, and the vote: Evidence from experiments in sweden and moldova. Electoral Studies 32(3), 535-543.

Kramer, G. H. (1971). Short-term fluctuations in us voting behavior, 1896-1964. American Political Science Review 65(01), 131-143.

Krosnick, J. A. (1990). Government policy and citizen passion: A study of issue publics in contemporary america. Political Behavior 12(1), 59-92.

Kurtz, M. J. and A. Schrank (2007). Growth and governance: Models, measures, and mechanisms. Journal of politics 69(2), 538-554. 
Lewis-Beck, M. S. and M. Stegmaier (2000). Economic determinants of electoral outcomes. Political Science 3(1), 183.

Lin, T.-m. (1999). The historical significance of economic voting, 1872-1996. Social Science History 23(4), 561-591.

Lupia, A. (1998). The democratic dilemma: Can citizens learn what they need to know? Cambridge University Press.

Manzetti, L. and C. J. Wilson (2007). Why do corrupt governments maintain public support? Comparative Political Studies 40(8), 949-970.

Marsh, M. (2002). Electoral context. Electoral studies 21(2), 207-217.

Marshall, M. G. and K. Jaggers (2012). Political regime characteristics and transitions, 1800-2010. Technical report, Polity IV Project.

Moulton, B. R. (1986). Random group effects and the precision of regression estimates. Journal of econometrics 32(3), 385-397.

Oliver, J. E. and S. E. Ha (2007). Vote choice in suburban elections. American Political Science Review $101(3), 393$.

Ostrom, E. (1999). Why do we need multiple indicators of public service outputs? In Polycentricity and local public economies: readings from the Workshop in Political Theory and Policy Analysis, pp. 163-175.

Parks, R. B. (1984). Linking objective and subjective measures of performance. Public Administration Review 44(2), 118-127.

Peters, J. G. and S. Welch (1980). The effects of charges of corruption on voting behavior in congressional elections. The American Political Science Review 74(3), 697-708.

Powell Jr, G. B. and G. D. Whitten (1993). A cross-national analysis of economic voting: taking account of the political context. American Journal of Political Science 37(2), $391-414$.

Ranney, A. (1982). The doctrine of responsible party government: Its origins and present state. Greenwood Press.

Rodrik, D., A. Subramanian, and F. Trebbi (2004). Institutions rule: the primacy of institutions over geography and integration in economic development. Journal of economic growth 9(2), 131-165.

Rothstein, B. and D. Stolle (2008). The state and social capital: An institutional theory of generalized trust. Comparative Politics 40(4), 441-459.

Sanders, D. and N. Gavin (2004). Television news, economic perceptions and political preferences in britain, 1997-2001. Journal of Politics 66 (4), 1245-1266. 
Shabad, G. and K. M. Slomczynski (2011). Voters' perceptions of government performance and attributions of responsibility: Electoral control in poland. Electoral studies 30(2), 309-320.

Singer, M. (2011a). When do voters actually think "it's the economy"? evidence from the 2008 presidential campaign. Electoral Studies 30(4), 621-632.

Singer, M. M. (2011b). Who says "it's the economy"? cross-national and cross-individual variation in the salience of economic performance. Comparative Political Studies 44(3), $284-312$.

Stokes, D. (1992). Valence politics. In D. Kavanagh (Ed.), Electoral politics, pp. 141-164. Clarendon Press, Oxford, UK.

Stokes, D. E. (1963). Spatial models of party competition. The American Political Science Review 57(2), 368-377.

Swindell, D. and J. M. Kelly (2000). Linking citizen satisfaction data to performance measures: A preliminary evaluation. Public Performance 63 Management Review 24(1), $30-52$.

Tucker, J. A. (2006). Regional Economic Voting: Russia, Poland, Hungary, Slovakia, and the Czech Republic, 1990-1999. Cambridge Univ Press.

UNPD (1997). Governance for sustainable human development. a undp policy document. United Nations Development Programme.

Van Ryzin, G. G. (2008). Citizen perceptions of road smoothness: evidence from new york with implications for comparative performance measurement. International Review of Administrative Sciences 74(4), 575-588.

Wlezien, C. (2005). On the salience of political issues: The problem with 'most important problem'. Electoral Studies 24(4), 555-579.

Wooldridge, J. M. (2003). Cluster-sample methods in applied econometrics. The American Economic Review 93(2), 133-138.

Zechmeister, E. J. and D. Zizumbo-Colunga (2013). The varying political toll of concerns about corruption in good versus bad economic times. Comparative Political Studies $46(10), 1190-1218$. 
Table 1: Ordinary least square regression of change in vote share of the prime minister's party

\begin{tabular}{|c|c|c|c|c|c|}
\hline & Model 1 & Model 2 & Model 3 & Model 4 & Model 5 \\
\hline Change in QoG & $\begin{array}{c}11.34^{* *} \\
(5.017)\end{array}$ & $\begin{array}{c}7.847 \\
(6.998)\end{array}$ & $\begin{array}{l}89.19^{* * *} \\
(17.56)\end{array}$ & $\begin{array}{c}10.89^{* *} \\
(5.071)\end{array}$ & $\begin{array}{c}54.07 \\
(84.15)\end{array}$ \\
\hline Economic growth & $\begin{array}{l}0.591^{* * *} \\
(0.205)\end{array}$ & $\begin{array}{l}0.643^{* * *} \\
(0.214)\end{array}$ & $\begin{array}{l}0.579^{* * *} \\
(0.206)\end{array}$ & $\begin{array}{c}3.156 \\
(2.642)\end{array}$ & $\begin{array}{c}1.879 \\
(3.673)\end{array}$ \\
\hline Previous vote share & $\begin{array}{c}-0.228^{* * *} \\
(0.079)\end{array}$ & $\begin{array}{c}-0.223^{* * *} \\
(0.080)\end{array}$ & $\begin{array}{c}-0.256^{* * *} \\
(0.080)\end{array}$ & $\begin{array}{c}-0.236^{* * *} \\
(0.082)\end{array}$ & $\begin{array}{c}-0.250^{* * *} \\
(0.085)\end{array}$ \\
\hline Good governance & $\begin{array}{c}0.807 \\
(1.194)\end{array}$ & $\begin{array}{c}0.682 \\
(1.179)\end{array}$ & $\begin{array}{c}0.267 \\
(1.189)\end{array}$ & $\begin{array}{c}0.715 \\
(1.197)\end{array}$ & $\begin{array}{c}0.175 \\
(1.192)\end{array}$ \\
\hline Democracy & $\begin{array}{r}-0.020 \\
(0.017)\end{array}$ & $\begin{array}{r}-0.022 \\
(0.017)\end{array}$ & $\begin{array}{r}-0.020 \\
(0.018)\end{array}$ & $\begin{array}{r}-0.019 \\
(0.017)\end{array}$ & $\begin{array}{r}-0.020 \\
(0.018)\end{array}$ \\
\hline Coalition & $\begin{array}{r}-0.875 \\
(1.544)\end{array}$ & $\begin{array}{r}-0.962 \\
(1.535)\end{array}$ & $\begin{array}{r}-1.239 \\
(1.549)\end{array}$ & $\begin{array}{r}-1.159 \\
(1.453)\end{array}$ & $\begin{array}{r}-1.267 \\
(1.524)\end{array}$ \\
\hline Recession & $\begin{array}{r}-2.512 \\
(2.074)\end{array}$ & $\begin{array}{r}-2.642 \\
(2.041)\end{array}$ & $\begin{array}{r}-3.068 \\
(2.075)\end{array}$ & $\begin{array}{r}-2.980 \\
(2.058)\end{array}$ & $\begin{array}{r}-3.281 \\
(2.088)\end{array}$ \\
\hline Economic development & $\begin{array}{l}3.162^{\text {*** }} \\
(0.959)\end{array}$ & $\begin{array}{l}3.415^{* * *} \\
(1.021)\end{array}$ & $\begin{array}{l}3.776^{* * *} \\
(0.668)\end{array}$ & $\begin{array}{l}3.972^{* * *} \\
(0.934)\end{array}$ & $\begin{array}{c}4.398^{* *} \\
(1.716)\end{array}$ \\
\hline Interaction1 & & $\begin{array}{c}1.203 \\
(1.486)\end{array}$ & & & $\begin{array}{r}7.572 \\
(18.27)\end{array}$ \\
\hline Interaction 2 & & & $\begin{array}{c}-8.254^{* * *} \\
(2.010)\end{array}$ & & $\begin{array}{r}-4.796 \\
(8.524)\end{array}$ \\
\hline Interaction3 & & & & $\begin{array}{c}-0.261 \\
(0.261)\end{array}$ & $\begin{array}{r}-0.130 \\
(0.363)\end{array}$ \\
\hline Interaction 123 & & & & & $\begin{array}{r}-0.735 \\
(1.816)\end{array}$ \\
\hline Constant & $\begin{array}{c}-31.08^{* * *} \\
(8.772)\end{array}$ & $\begin{array}{c}-33.20^{* * *} \\
(9.884)\end{array}$ & $\begin{array}{r}-33.21^{* * *} \\
(7.044)\end{array}$ & $\begin{array}{c}-38.27^{* * *} \\
(8.813)\end{array}$ & $\begin{array}{c}-39.20^{* *} \\
(17.86)\end{array}$ \\
\hline Observations & 160 & 160 & 160 & 160 & 160 \\
\hline R-squared & 0.286 & 0.289 & 0.321 & 0.293 & 0.322 \\
\hline $\begin{array}{l}* * *: p \leq .01 ; * *: p \leq .0 \\
\text { Interaction } 1=\text { Change } \\
\text { Interaction } 2=\text { Change } \\
\text { Interaction } 3=\text { Economi } \\
\text { Interaction } 123=\text { Chang }\end{array}$ & $\begin{array}{l}p \leq .10 \\
\text { od govern } \\
\text { od govern } \\
\text { owth } * \text { Ecc }\end{array}$ & $\begin{array}{l}\text { ce } * \text { Econo } \\
\text { ce }{ }^{*} \text { Econo } \\
\text { omic devel }\end{array}$ & $\begin{array}{l}\text { c growth } \\
\text { c develop } \\
\text { nent }\end{array}$ & ht & \\
\hline
\end{tabular}


Table 2: Expected change in vote share (\%) for the prime minister's party for different levels of economic growth, change in good governance and wealth

\begin{tabular}{|c|c|c|c|}
\hline $\begin{array}{c}\text { C.gov } \\
\text { E.growth }\end{array}$ & $\begin{array}{c}\text { Low } \\
\text { (M-1sd) }\end{array}$ & $\begin{array}{c}\text { Average } \\
(\mathrm{M})\end{array}$ & $\begin{array}{c}\text { High } \\
(\mathrm{M}+1 \mathrm{sd})\end{array}$ \\
\hline & \multicolumn{3}{|c|}{ Low economic development } \\
\hline Low & $-9.39(-12.40,-6.30)$ & $-7.99(-12.77,-$ & $7(-1)$ \\
\hline Average & $-7.61(-10.70,-4.33)$ & $-5.63(-8.67,-2$ & $-3.93(-7.81,-0.34)$ \\
\hline High & $14(-10.15,-1.83)$ & $-3.61(-6.88,-0.23)$ & $-1.71(-4.99,1.62)$ \\
\hline & \multicolumn{3}{|c|}{ Average economic development } \\
\hline Low & $-4.36(-8.18,-0.45)$ & $-3.44(-6.92,-0.28)$ & $-2.70(-6.87, \quad 1.22)$ \\
\hline Average & $-2.65(-5.85,0.71)$ & $-1.78(-4.69, \quad 1.51)$ & $-0.92(-4.61,2.54)$ \\
\hline High & $07(-4.38,2.16)$ & $-0.24(-3.55,3.00)$ & $0.65(-3.36,4.76)$ \\
\hline & \multicolumn{3}{|c|}{ High economic developmen } \\
\hline Low & $-1.77(-6.30, \quad 2.51)$ & $-1.28(-5.23,2.60)$ & $-0.98(-6.00,4.06)$ \\
\hline Aver & $-0.22(-3.72,3.22)$ & $0.19(-3.23, \quad 3.50)$ & $0.42(-3.60,4.33)$ \\
\hline High & $1.30(-2.23,4.77)$ & $1.60(-2.56,5.33)$ & $1.66(-3.11,6.57)$ \\
\hline
\end{tabular}

Note: Expected values and their 95\% confidence intervals (in parantheses) calculated using Clarify (King et al. 2000) based on the results in Model 5 (Table 1). Economic growth(E.growth), change in good governance (C. gov) and economic development level are at their mean (Average, $\mathrm{M}$ ), mean minus one standard deviation (Low, M-1sd) and mean plus one standard deviation (High, $\mathrm{M}+1 \mathrm{sd})$ 
Figure 1: The contingent marginal effect of change in good governance and economic growth on vote share and their $95 \%$ confidence intervals
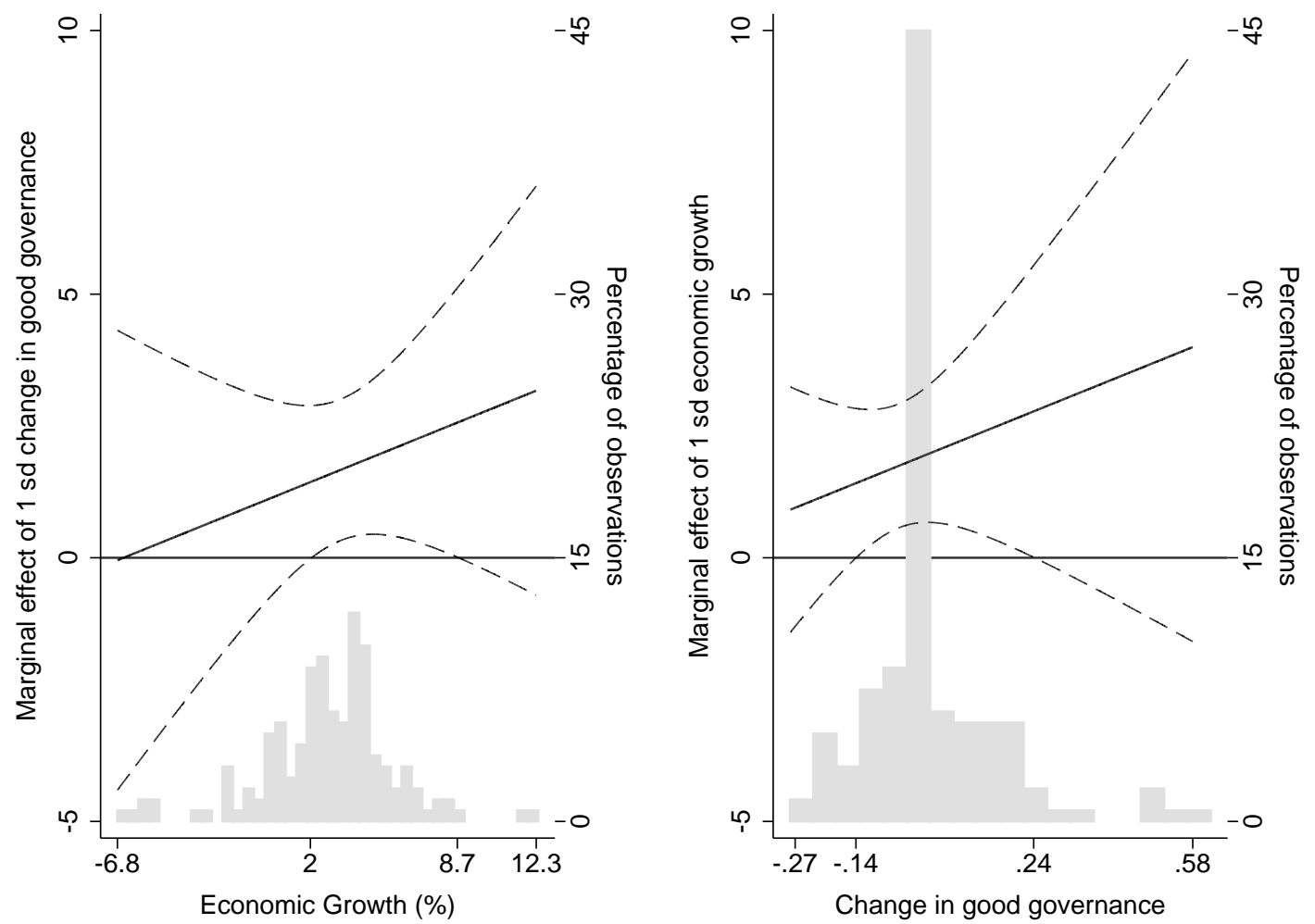

The marginal effect plots are constructed using Berry et al.'s (2012) indications based on the results in model 2 in Table 1. The vertical axes on the left indicate the magnitude of the marginal effect. The vertical axes on the right are for the histogram, which depicts the distribution of observations in the sample on the variable on the horizontal axis. The bars of the economic growth histogram have width 5 and of change in good governance 0.05 . 
Figure 2: The marginal effect of change in good governance and economic growth on vote share and their $95 \%$ confidence intervals across the observed range of economic wealth
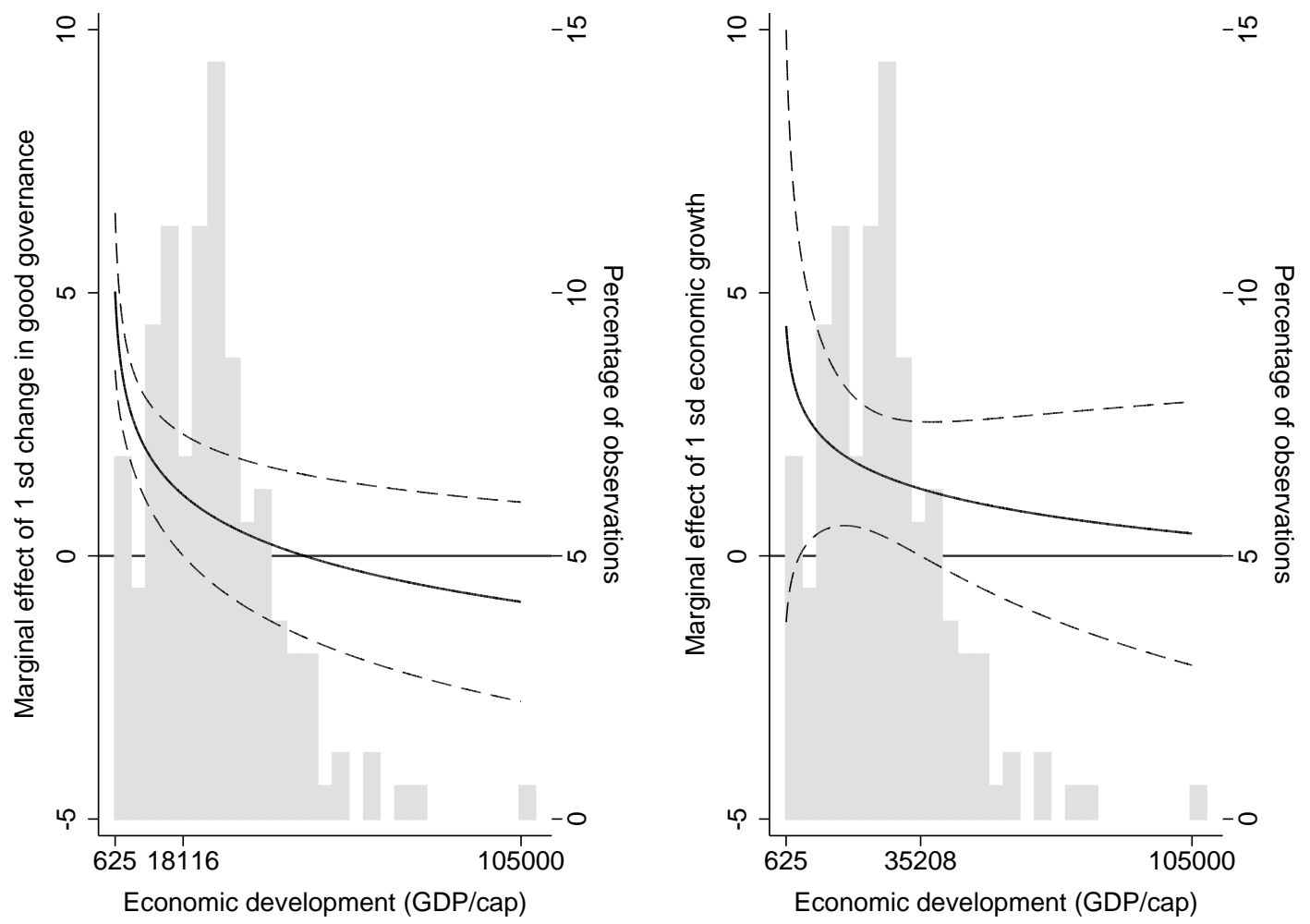

The marginal effect plots are constructed using Berry et al.'s (2012) indications based on the results in models 3 and 4 in Table 1 . The vertical axes on the left indicate the magnitude of the marginal effect. The vertical axes on the right are for the histogram, which depicts the distribution of observations in the sample on the variable on the horizontal axis. The bars of the histogram have width 4000 . 
Figure 3: The marginal effect of change in good governance and economic growth on vote share and their $95 \%$ confidence intervals from a three way interaction with economic wealth
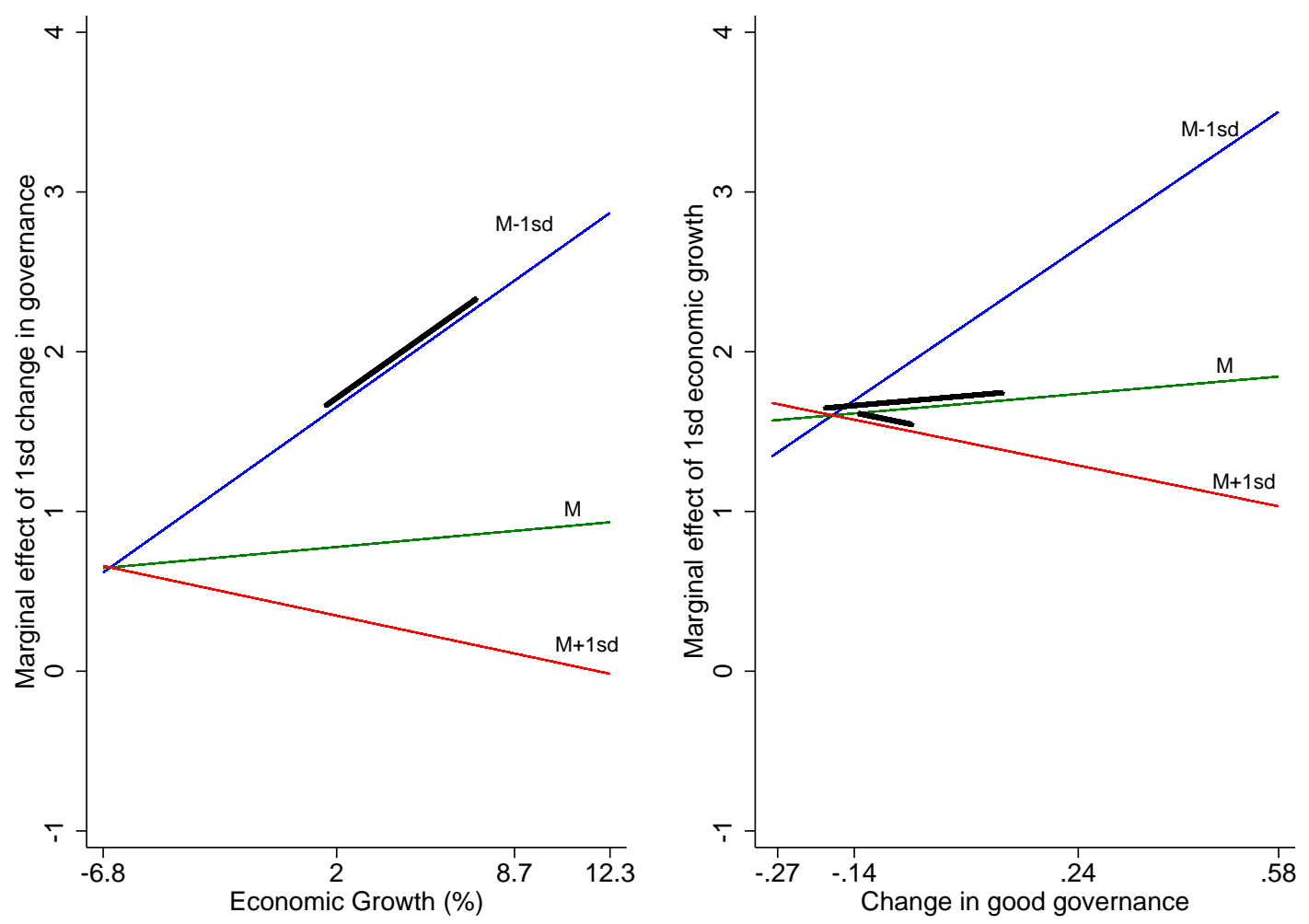

The marginal effect plots are constructed using Berry et al.'s (2012) indications based on the results in model 5 in Table 1. The vertical axes on the left indicate the magnitude of the marginal effect. This effect was calculated for three different values of economic wealth: its mean minus one standard deviation (blue line, GDP $/$ cap $=\$ 9,500$ ), its mean (green line, GDP $/$ cap $=\$ 25,800$ ) and its mean plus one standard deviation (red line, GDP/cap=\$42,000). The thick extra line indicates the values on $\mathrm{x}$-axis for which the marginal effect is statistically significant at a $5 \%$ level. 
Figure 4: The coefficient estimates of change in good of governance and economic growth, and the effects of measurement error in variable change in good governance in models of support for the incumbent
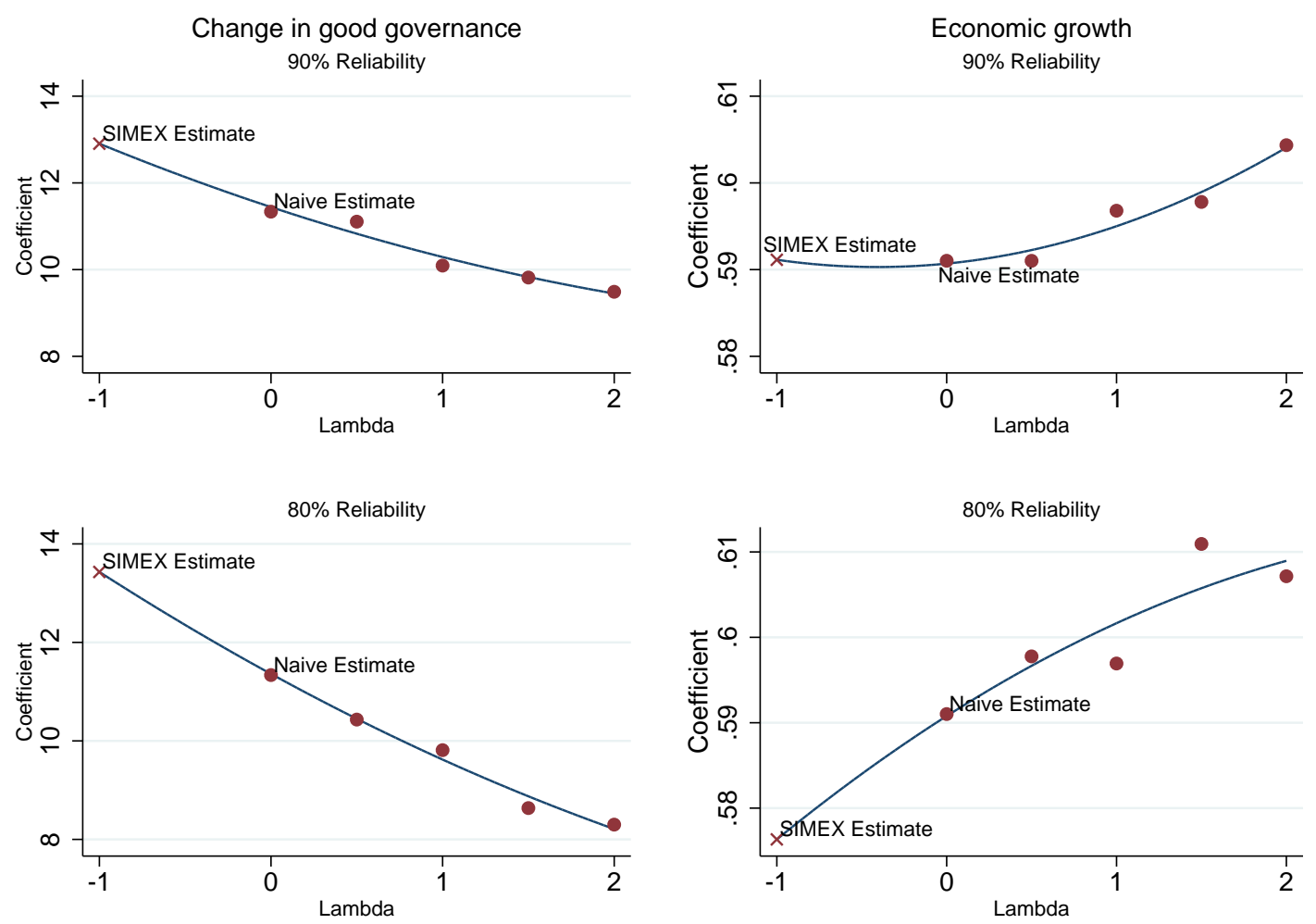

The graphs show the coefficient estimates for change in quality of governance and economic growth in Model 1 (Table 1) when quality of governance and the change of governance are measured with error. I calculate the coefficients of change in governance and economic growth for two situations: when the reliability of governance and change in governance is $80 \%$ (upper graphs) or $90 \%$ (lower graphs). I assume the covariance between the errors of both indicators to be 0 . 